\title{
Geochemistry and oxygen isotopic composition of the Canton Saint-Onge wollastonite deposit, central Grenville Province, Canada
}

\author{
Michael D. Higgins, Arlene Beisswenger, and Lawrence D. Hoy
}

\begin{abstract}
The geology and geochemistry of the Canton Saint-Onge wollastonite deposit indicate that it is a skarn formed by silica metasomatism of dolomite-rich rocks. Oxygen isotopic compositions of the skarn rocks and the nearby plutons show that the fluids responsible for the metasomatism were not meteoric, but were probably associated with the Du Bras granitic pluton. However, the granite is not in contact with the wollastonite rocks at the present level of exposure, hence the fluids must have been released at greater depths. Wollastonite-rich parts of the skarn rocks are isotopically lighter than diopside-rich rocks, suggesting that wollastonite formed in regions of higher fluid flux.
\end{abstract}

\begin{abstract}
Résumé : La géologie et la géochimie du dépôt de wollastonite du canton Saint-Onge indiquent qu'il s'agit d'un skarn formé par le métasomatisme de la silice de roches riches en dolomie. Les compositions isotopiques de l'oxygène des roches skarnifiées et des plutons avoisinants montrent que les fluides responsables du métasomatisme n'étaient pas d'origine météorique mais qu'ils étaient plutôt associés au pluton granitique de Du Bras. Toutefois, le granite n'est pas en contact avec les roches à wollastonite au présent niveau d'affleurement; les fluides auraient donc été relâchés à de plus grandes profondeurs. Les parties riches en wollastonite des roches du skarn sont isotopiquement plus légères que les roches à diopside, indiquant que la wollastonite s'est formée dans des régions à très grand écoulement.
\end{abstract}

[Traduit par la Rédaction]

\section{Introduction}

Wollastonite is the naturally occurring anhydrous calcsilicate, $\mathrm{CaSiO}_{3}$. It is an important industrial mineral and is particularly valuable for ceramic applications, and as a whitener for paint, a filler for plastics, and a flux (Andrews 1970). Recently, an important new deposit of wollastonite was found in the Grenville structural province, in a band of northwest-trending metasediments situated near the centre of the Lac Saint-Jean Anorthosite Suite in Canton Saint-Onge (Fig. 1). The Canton Saint-Onge deposit has probable and possible open-pit reserves totalling 26 million tonnes grading at $37 \%$ wollastonite (Christie 1994). The reserves are contained in a block $2.3 \mathrm{~km}$ long by $100 \mathrm{~m}$ deep, with a true width that averages $60 \mathrm{~m}$.

Wollastonite is a common constituent of thermally metamorphosed impure limestones and is also the product of metasomatism where silica is added to calcareous sediments. It is usually formed by the reaction

$$
\begin{aligned}
\operatorname{calcite}(\mathrm{s})+ & \mathrm{SiO}_{2}(\mathrm{aq} \text { or } \mathrm{s})= \\
& \text { wollastonite }(\mathrm{s}) \\
& +\operatorname{carbon} \operatorname{dioxide}(\mathrm{g})
\end{aligned}
$$

The presence of significant quantities of other components in the system, such as $\mathrm{Mg}, \mathrm{Al}$, and $\mathrm{OH}$, will lead to the development of other reactions and the formation of diopside, grossular-andradite garnet, chondrodite, vesuvianite, tremolite, and other calc-silicates. Although the carbonate minerals dolomite and magnesite will react with quartz under low-grade metamorphic conditions, this is not true for calcite.

Figure 2 shows the stability of calcite + quartz for different mole fractions of $\mathrm{CO}_{2}$ (Greenwood 1967; Harker et al. 1956; Holland and Powell 1990; Powell and Holland 1988). Curve $\mathrm{A}$ is a typical equilibrium geotherm (Fowler and Nisbet 1982) for a rock during burial regional metamorphism. The exact position of this curve is not important, just that it only intersects the stability curve for wollastonite at low mole fractions of $\mathrm{CO}_{2}$, and then only at high temperatures and pressures. Low mole fractions of $\mathrm{CO}_{2}$ during prograde metamorphism of carbonate rocks can only be achieved if the $\mathrm{CO}_{2}$ is diluted by $\mathrm{H}_{2} \mathrm{O}$, for example by the dehydration of $\mathrm{H}_{2} \mathrm{O}$-rich pelites (MacKinnon 1990).

Curve B in Fig. 2 is a typical thermal gradient of contact metamorphism of rocks near a cooling pluton (taken from Winkler 1974). Here, the geothermal gradient is much higher, resulting in the crystallization of wollastonite in sili-

Received July 10, 2000. Accepted January 24, 2001. Published on the NRC Research Press Web site at http://cjes.nrc.ca on Aug 7, 2001.

Paper handled by Associate Editor J. Greenough.

M.D. Higgins ${ }^{1}$ and A. Beisswenger. Université du Québec à Chicoutimi, Chicoutimi, QC G7H 2B1, Canada.

L.D. Hoy. Département de géologie, Université de Montréal, P.O. Box 6128, Succursale Centre-Ville, Montréal, QC H3C 3A7, Canada.

${ }^{1}$ Corresponding author (e-mail: mhiggins@uqac.uquebec.ca). 
Fig. 1. Geology of the Grenville Province. Divisions after Rivers et al. (1989). LSJPSZ, lacs Saint-Jean - Pipmuacan Shear Zone.

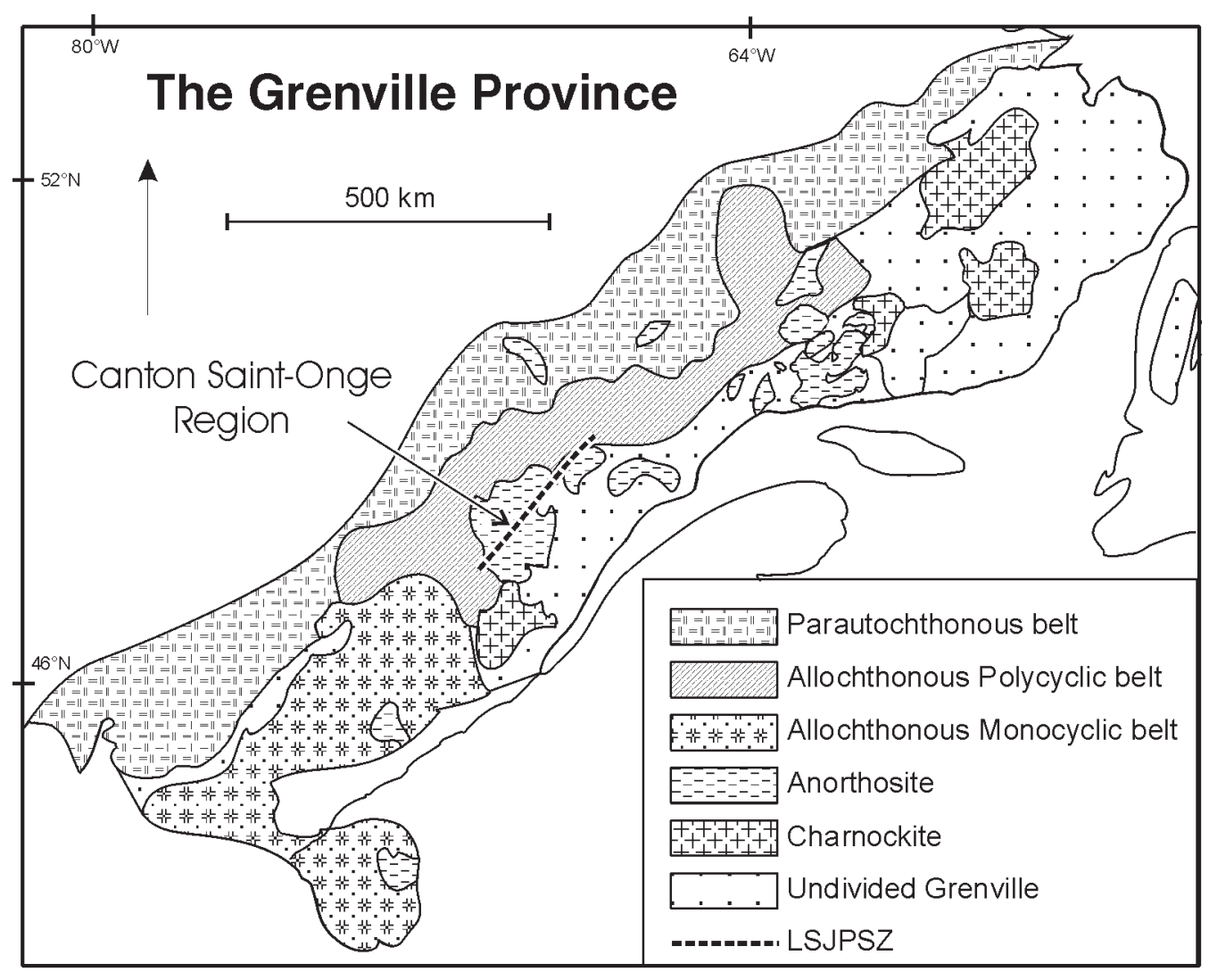

Fig. 2. Stability of calcite + quartz. The continental geotherm is from Winkler (1974). The typical geotherm adjacent to an intrusion is from Fowler and Nisbet (1982). The stability of calcite + quartz for different fluid compositions $\left(\mathrm{X}_{\mathrm{CO} 2}\right)$ was based on experimental data to $3 \mathrm{kbar}$ (1 kbar = $100 \mathrm{MPa}$; Greenwood 1967; Harker and Tuttle 1956) extended to $10 \mathrm{kbar}$ using the program Thermocalc and the thermodynamic data of Holland and Powell (1990) and Powell and Holland (1988).

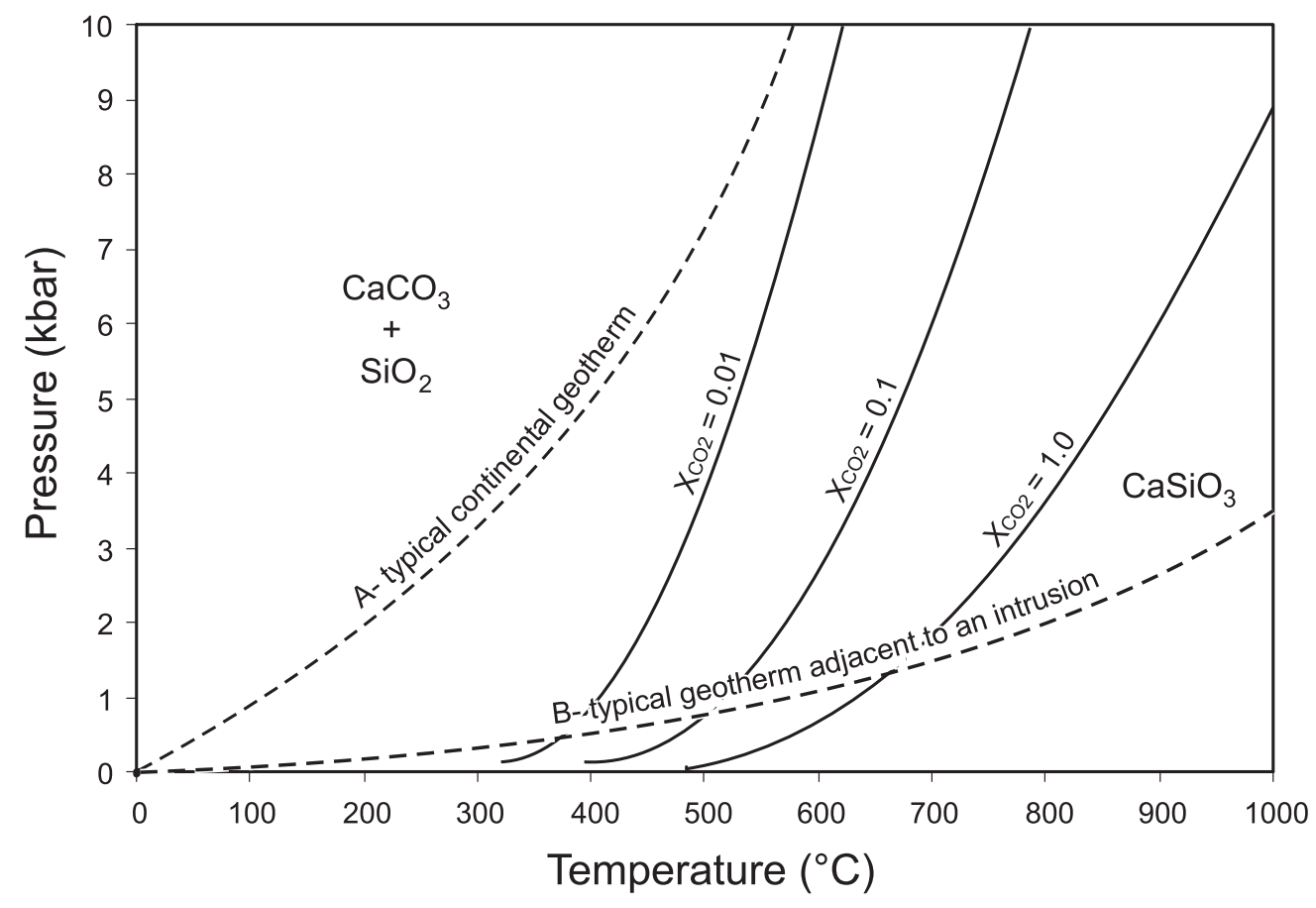


Fig. 3. Geology of the Canton Saint-Onge region, following Gervais (1993). Numbers are oxygen isotopic compositions in \%o.

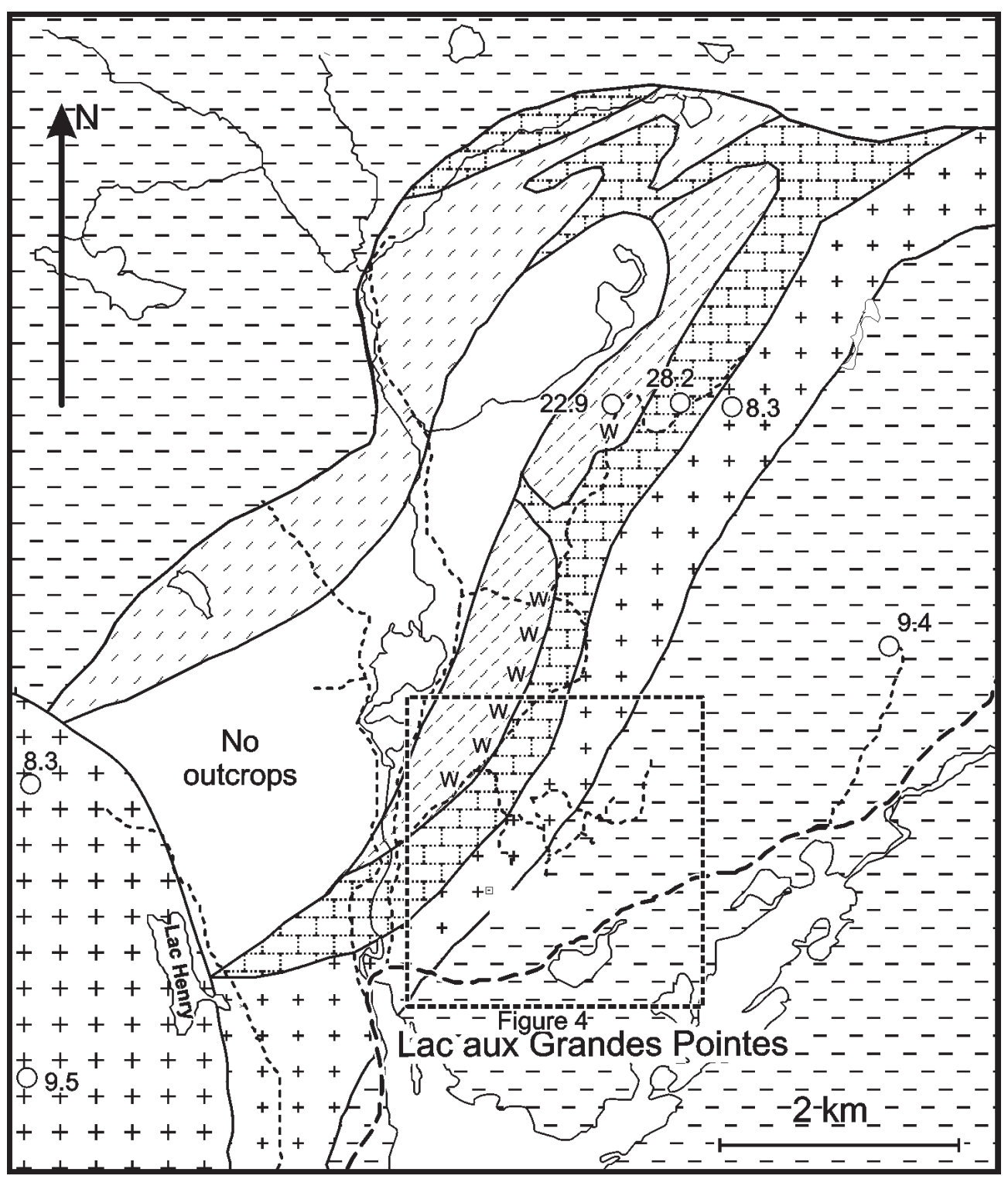

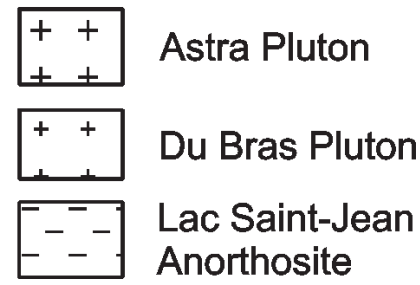

ceous marbles at temperatures around $600^{\circ} \mathrm{C}$ for intrusions at a depth of $3 \mathrm{~km}(1 \mathrm{kbar}$ or $100 \mathrm{MPa})$ for a mole fraction of $\mathrm{CO}_{2}$ of 0.8 (Winkler 1974). As for curve A, lower mole fractions of $\mathrm{CO}_{2}$, produced by dilution of the fluid with $\mathrm{H}_{2} \mathrm{O}$, will lead to production of wollastonite at lower temperatures (MacKinnon 1990).

Wollastonite can also be formed from relatively pure calcite, where the silica is added by the infiltration and diffusion of silica-bearing metasomatic fluids from outside the marble, for example those associated with granites. This fluid interacts with the carbonate and yields skarn rocks

\section{Calc-silicate rocks}

\section{Wollastonite-bearing facies}

Marble restricted to well-defined zones at the contact of the marbles and granitoids (Greenwood 1967). The width of the wollastonite zone is dependant on the depth of penetration of fluids migrating from the igneous body. Again, the mole fraction of $\mathrm{CO}_{2}$ in the fluids is a critical parameter.

The Canton Saint-Onge wollastonite deposit is spatially associated with anorthosite and granitoid intrusions. The purpose of this study was to determine how it formed: was it by contact metamorphism of siliceous, calcite-rich marbles by the granitoids or metasomatism of purer marble? If the latter, then the source of the fluids must also be ascertained. 


\section{Regional geology}

\section{Introduction}

The Saguenay - Lac Saint-Jean area (SLSJ) lies in the central part of the Grenville Province, within the Allochthonous Polycyclic Belt of Rivers et al. (1989; Fig. 1). The oldest rocks are granulite and upper amphibolite-facies gneissic rocks, containing paragneisses of uncertain age. The area is cut by numerous large plutons, many of which are anorthositic and mangeritic in composition (Roy et al. 1986). Most of the intrusions appear to have been emplaced during three periods: 1400, 1160-1140, and 1080-1010 Ma (Higgins and van Breemen 1996). The most important unit is the Lac Saint-Jean Anorthosite Suite (LSJAS), which covers more than $20000 \mathrm{~km}^{2}$.

The Canton Saint-Onge wollastonite deposit is located within a major northeast-southwest-trending shear zone, termed the lacs Saint-Jean - Pipmuacan Shear Zone (LSJPSZ; Hébert 1991), which bisects the LSJAS. This shear zone can be traced from the northeast extremity of the Pipmuacan reservoir to Dolbeau, near Lac Saint-Jean, for a distance of at least $200 \mathrm{~km}$. It is marked by solid-state deformation, mylonites, and faults oriented $\mathrm{N} 050^{\circ}$ to $\mathrm{N}^{\circ} 60^{\circ}$. Numerous intrusions of diverse composition, including granite, syenite, gabbro, and charnockite, were emplaced into the shear zone. Deformation is very variable both within and between the plutons, suggesting a complex interplay between movement along the shear zone and plutonic emplacement (Hébert 1991).

\section{The Canton Saint-Onge region}

The oldest rocks in the Canton Saint-Onge (CSO) region are the block of metasediments that host the wollastonite deposit. These are but one of a series of lenses of paragneiss, calc-silicates, and marbles that are found along the LSJPSZ and elsewhere in the SLSJ area. Their geographical distribution suggested to Gervais (1993) that they represent roof pendants metamorphosed by the intruding anorthosite mass. However, their close association with the shear zone suggests that they could also represent fault-bounded blocks dropped down by late renewed movement, hence preserving them from subsequent erosion. The depositional age of these rocks is not known, but they must predate the oldest part of the LSJAS at 1157 Ma (Higgins and van Breemen 1996). The metasedimentary rocks of the CSO region are described here briefly. The plutonic rocks of this region have been the subject of a recent detailed geochemical and geochronological study (see later in this paper; Beisswenger 1997; Ider et al. 1997) and are described here briefly for context.

\section{Anorthosite}

The LSJAS surrounds the CSO region (Fig. 1, 3). In this region, and elsewhere, the LSJAS is variable in composition, from true anorthosite to leucogabbro and leucotroctolite (Dimroth et al. 1981; Roy et al. 1986; Woussen et al. 1981). Solid-state deformation of the LSJAS was extremely heterogeneous: some areas retain almost pristine igneous textures, whereas elsewhere the anorthosite has been transformed into a grey, plagioclase-rich gneiss. The foliation plane resulting from emplacement is commonly subvertical in this region and commonly parallel to the LSJPSZ. Where orthopyroxene- amphibole coronas developed between olivine and plagioclase, they postdate the deformation (i.e., the minerals in the coronas show no sign of crystal-plastic deformation features).

\section{Du Bras pluton}

The Du Bras pluton is dominantly of granitic composition and lies between the anorthosite and the marbles (Figs. 3, 4). It is comprised of quartz, which is commonly blue, perthitic orthoclase, plagioclase with minor biotite, hornblende, titanite, epidote, apatite, pyrite, and zircon. Solid-state deformation is of variable extent, but mortar texture is fairly common. The pluton is most strongly deformed in the southwest, as demonstrated by the presence of a strong foliation, rotated phenocrysts, and shear bands. The position of this intrusion suggested to Gervais (1993) that this unit is a granophyre, produced by melting of siliceous metasediments during the emplacement of the Lac Saint-Jean Anorthosite. This idea is supported by the similarity in age of the Du Bras pluton and the LSJAS (see later in this paper). However, the Du Bras pluton is never in direct contact with the siliceous metasedimentary rocks, only the marbles. Hence, melting must have occurred at greater depths.

\section{Astra pluton}

The subcircular Astra pluton stitches the LSJPSZ (Fig. 3). It is a syenite comprised of microcline (60\%), quartz (30\%), and minor plagioclase, hornblende, biotite, apatite, magnetite, and zircon. It is generally undeformed in the solid state, although a weak foliation defined by the alignment of feldspar is probably magmatic in origin.

\section{Marbles}

The marbles dominate the southeastern part of the metasedimentary lens, following the edge of the Du Bras pluton (Figs. 3, 4). They can be divided into three varieties: massive metadolostone, layered olivine-serpentine marble, and calc-silicate marble. The first two varieties are not traceable on the deposit scale. The third variety only occurs near to the calc-silicates. All varieties are complexly folded.

The massive metadolostone is white, massive to faintly layered, and composed principally of equant dolomite (1 mm, 90\%), with minor calcite, serpentine, olivine, and graphite. Yellow chondrodite also occurs in the southwestern parts of this unit $(5-30 \%)$.

The layered serpentine-olivine marble is dominated by calcite $(50-65 \%)$ with a mixture of olivine and retrograde serpentine $(\sim 30 \%)$. Other minor minerals are muscovite, quartz, and graphite, but magnesite is absent. Layering is produced by grain-size variation, and modal variations of serpentine or olivine. The layers are continuous and can be traced along the exposure of the outcrops or trenches. Chondrodite also occurs in this unit (5-30\%), but only in the southwest close to the contact with the Astra pluton.

The calc-silicate marble differs from the other varieties by the presence of significant quantities of diopside. This rock is generally found near the contact between the calc-silicate rocks and the marble and, therefore, may represent a transitional stage between the two. However, it is classified as a marble because of its high calcite content $(>40 \%)$. This rock is layered in some places, with layers of calcite between lay- 
Fig. 4. The central part of the Canton Saint-Onge wollastonite deposit, following Gervais (1993). Numbers are oxygen isotopic compositions in \%o. Legend as in Fig. 3.

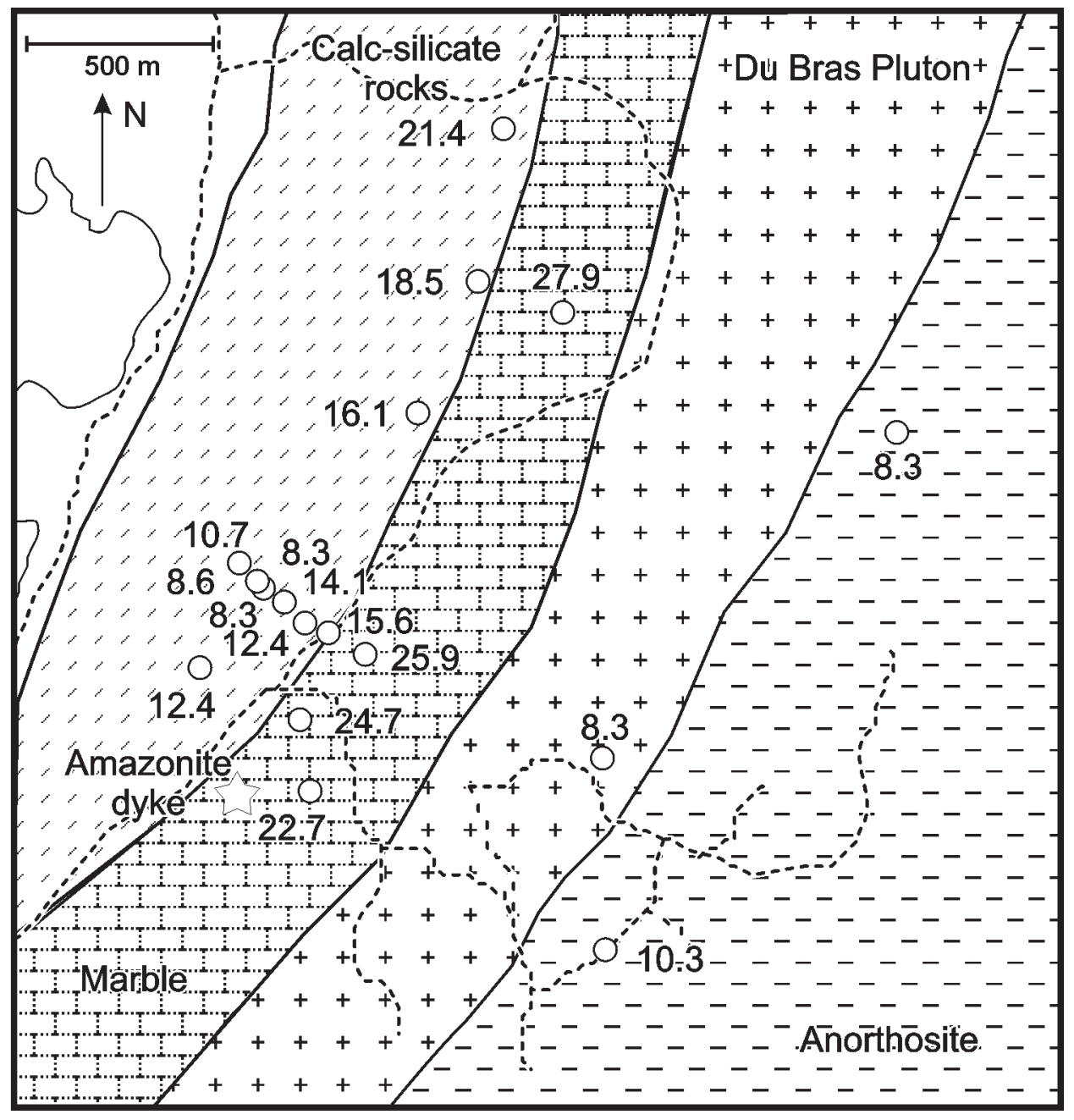

ers of diopside, wollastonite, and titanite. Elsewhere, it is massive, composed mainly of calcite $(\sim 70 \%)$ together with quartz, diopside, perthite, graphite, biotite, and titanite.

\section{Calc-silicate rocks}

The calc-silicate rocks form the rest of the metasedimentary lens, mostly to the northeast of the marbles (Figs. 3, 4). They are dominated by diopside, in various forms and colours, in some areas interlayered with wollastonite. This "layer cake" wollastonite-diopside rock is found mainly near the contact with the marble, on its southern side. The layering at the millimetre to centimetre scale is easily distinguished by the difference in colour (diopside is green and wollastonite white) and the preferential weathering of the wollastonite layers. The layers of quartz and diopside resist weathering, whereas the wollastonite weathers easily, leaving a fibrous mush. The calc-silicate rocks lacking wollastonite are hereafter termed "barren calc-silicate rocks." Both barren and wollastonite-bearing calc-silicates rocks are commonly folded.

The calc-silicate rocks are comprised of diopside, wollastonite, quartz, titanite, and microcline. Accessory minerals include calcite, plagioclase, vesuvianite, tremolite, anthophylite, pyrrhotite, and chalcopyrite. Diopside (50$98 \%$ ) is typically granoblastic in texture. In some samples, there is a grain-size-defined layering. Diopside can be green, grey, brown, or white. The diopside associated with the wollastonite is commonly green.

The wollastonite is generally coarse grained, up to $6 \mathrm{~mm}$ long with an aspect ratio of 1:3. Grains are always larger than those of diopside, which dominates the mineral assemblage. The wollastonite laths are usually crudely aligned with the layering in the rock and are concentrated in layers alternating with the diopside-rich layers. The wollastonite is commonly poikilitic, with inclusions mainly of diopside and quartz.

Titanite is common in parts of this unit (up to 30\%). It is pink in colour and anhedral and was mistaken for garnet by earlier workers. However, flotation experiments with very large samples indicate that the deposit only contains trace quantities of garnet (K. Khobzi, personal communication). Titanite is commonly evenly distributed as an accessory mineral, but occasionally occurs as thin layers less than $1 \mathrm{~mm}$ thick.

Quartz occurs concentrated as layers as well as disseminated throughout the rock, where it makes up $2-10 \%$ or 
rarely $40 \%$ of the rock. It is found in areas where there is less wollastonite. Quartz was never observed to be in contact with calcite. Calcite is found in small quantities $(<5 \%)$ in nearly all thin sections. Some grains are primary with a subhedral to euhedral habit, whereas others are secondary, filling in small late fractures.

Sulphide minerals in the samples include pyrite, pyrrhotite, chalcopyrite, and sphalerite. The pyrite, pyrrhotite, and chalcopyrite occur disseminated throughout the rock, although somewhat more concentrated in the diopside-rich layers, in quantities never exceeding $2 \%$. The sphalerite occurs only in one area, where entire layers up to $3 \mathrm{~cm}$ thick consist of nearly massive sphalerite, with zinc percentages up to $19.5 \%$ (Gervais 1993). This area was the focus of exploration by the company Soquem in 1978 and 1979.

\section{Geochronology}

Ider et al. (1997) have studied the geochronology of the region using $\mathrm{U}-\mathrm{Pb}$ mineral methods. They found that the $\mathrm{Du}$ Bras pluton (1148 $\pm 5 \mathrm{Ma})$ is broadly cotemporal with the LSJAS, both in this region (1137-1150 Ma) and to the south (1142-1157 Ma; Higgins and van Breemen 1996). The Astra pluton and amazonite pegmatite dyke are much younger $(1028 \pm 2 \mathrm{Ma})$ than these units. Titanite in the wollastonitebearing calc-silicate rocks has been dated at $1160 \pm 20 \mathrm{Ma}$. There is very little or no titanite in the marbles, hence these ages are unlikely to be inherited from the protolith. Hence, the calc-silicate rocks are considered to be broadly cotemporal with the LSJAS and Du Bras plutons. A report on this work is in preparation.

\section{Geochemistry}

\section{Methods}

X-ray fluorescence and inductively coupled plasma emission spectroscopy (ICP-ES) analyses were carried out at the Centre de recherches minérales (CRM) in Québec City. Other trace elements, including the rare-earth elements (REE), were analyzed by instrumental neutron activation (INAA). These samples were irradiated at the École Polytechnique in Montréal and were counted at the Université du Québec à Chicoutimi. Representative analyses are shown in Table $1 .^{2}$

\section{Data}

\section{Marbles}

Almost all the marbles have high $\mathrm{MgO}, \mathrm{CaO}$, and loss on ignition (LOI), reflecting the dominance of carbonates in these rocks (Table 1). The metadolostone and the olivineserpentine marble units both have around the same quantity of $\mathrm{MgO}(\sim 20$ wt. $\%)$ despite their differing mineralogy; the magnesium in the former is partly contained in the dolomite, in the latter it is in the olivine or serpentine. All subunits are poor in iron with respect to magnesium. The olivine-serpentine and calc-silicate marbles have more silica than the dolostones, in accordance with the presence of diopside and olivine, respectively. Alkali elements are very low in all samples. $\mathrm{Ti}, \mathrm{Zr}$, and REE are very variable, with some samples having values similar to those of the calc-silicates (Table 1). The concentrations of these elements may indicate the presence of variable quantities of heavy minerals, such as zircon and ilmenite, in the original limestone.

\section{Barren calc-silicate rocks}

Barren calc-silicates are rich in silica, with only two samples departing significantly from the mean of $55 \%$. $\mathrm{MgO}$ contents are bimodal, with roughly half the samples having values similar to those of the marbles (16-20\%) and the others having only $5-10 \%$. $\mathrm{CaO}$ is broadly similar to that of the marbles. Fe/ $\mathrm{Mg}$ ratios are low, but overall iron contents are higher $(\mathrm{FeO}=0.3-2.5 \%)$ than in the carbonate rocks $(\mathrm{FeO}=$ $0-1.3 \%$ ). Alkali contents are variable from 0 to $1.1 \% \mathrm{Na}_{2} \mathrm{O}$ and $2.6 \% \mathrm{~K}_{2} \mathrm{O}$. Sr and $\mathrm{Ba}$ are much more abundant than in the marbles. $\mathrm{Ti}, \mathrm{Zr}$, and $\mathrm{REE}$ are variable, but again much higher than in the marbles.

\section{Wollastonite-bearing calc-silicate rocks}

The wollastonite-bearing calc-silicate rocks resemble geochemically the barren calc-silicates, although the range in values can be different. $\mathrm{MgO}$ is always in the range of 5$10 \%$. Silica is more variable than the barren rocks; one sample has $80 \% \mathrm{SiO}_{2}$, almost bridging the gap to the quartzites. LOI is generally low, as in the barren rocks, except for samples abm-068 and abm-111, which have $\sim 7 \%$, reflecting abundant calcite. Sample abm-077 has anomalously high zinc $(3.7 \%)$ and is from the zinc showing on the property.

\section{Oxygen isotopes}

\section{Analytical methods}

Twenty-nine whole-rock samples were analyzed at the stable isotope laboratory of the Université de Montréal. The method used for isotopic analysis is that of Clayton and Mayeda (1963). Between 4 and $6 \mathrm{mg}$ of rock powder was reacted with bromine pentaflouride $\left(\mathrm{BrF}_{5}\right)$ for at least $12 \mathrm{~h}$ in nickel tubes at around $600^{\circ} \mathrm{C}$. After collection and measurement of the quantity of oxygen (to determine yield), the gas was passed over hot carbon to convert it quantitatively to carbon dioxide. The carbon dioxide was then analyzed with a Nuclide 6-60-RMS mass spectrometer to determine the isotopic ratios.

\section{Data}

The locations of the samples used for isotope analysis are shown in Figs. 3 and 4, and the results are summarized in Table 2 and Fig. 8. The Du Bras pluton and the Astra pluton have $\delta^{18} \mathrm{O}$ values between 8 and $10 \%$, typical of plutonic granites (Taylor and Sheppard 1986), implying no contamination from high- $\delta^{18} \mathrm{O}$ crustal sources or interaction with meteoric water. The LSJAS anorthosite samples have $\delta^{18} \mathrm{O}$ values ranging from 8 to $11 \%$. These values are high for mafic rocks, but typical of Massif-type anorthosites that probably originated as high- $\delta^{18} \mathrm{O}$ magmas (Ashwal 1993; Valley 1986).

\footnotetext{
${ }^{2}$ The complete set of 40 analyses can be purchased from the Depository of Unpublished Data, Document Delivery, CISTI, National Research Council of Canada, Ottawa, ON K1A 0S2, Canada.
} 
Table 1. Representative analyses of metasedimentary rocks from the Canton Saint-Onge region.

\begin{tabular}{|c|c|c|c|c|c|c|c|c|c|c|}
\hline \multirow{2}{*}{$\begin{array}{l}\text { Rock type: } \\
\text { Sample No.: }\end{array}$} & \multicolumn{3}{|l|}{ Marble } & \multicolumn{3}{|c|}{ Calc-silicate } & \multicolumn{3}{|c|}{ Wollastonite calc-silicates } & \multirow{2}{*}{$\frac{\text { Quartzite }}{\text { abm-139 }}$} \\
\hline & abm-011 & abm-089 & abm-122b & abm-074 & abm-140 & abm-077 & abm-111 & abm-039 & abm- 022 & \\
\hline $\mathrm{SiO}_{2}$ (wt.\%) & 0.9 & 3.7 & 14.9 & 52.6 & 54.3 & 62.6 & 44.0 & 55.0 & 57.9 & 94.5 \\
\hline $\mathrm{Al}_{2} \mathrm{O}_{3}$ & 0.16 & 0.06 & 0.19 & 0.08 & 0.96 & 2.38 & 1.64 & 2.50 & 3.28 & 1.05 \\
\hline $\mathrm{FeO} *$ & & 0.24 & 0.56 & 0.30 & 1.21 & 2.46 & 0.79 & 1.17 & 1.24 & 0.23 \\
\hline $\mathrm{MnO}$ & 0.02 & & 0.04 & 0.03 & 0.14 & 0.34 & 0.04 & 0.04 & 0.06 & \\
\hline $\mathrm{Na}_{2} \mathrm{O}$ & & & & & 0.25 & 0.48 & 0.30 & 0.72 & 0.98 & 0.26 \\
\hline $\mathrm{K}_{2} \mathrm{O}$ & & & & & 0.44 & 1.20 & 0.81 & 1.21 & 1.41 & 0.52 \\
\hline $\mathrm{P}_{2} \mathrm{O}_{5}$ & & & & & & 0.07 & 0.04 & 0.02 & 0.07 & 0.01 \\
\hline LOI & 45.6 & 44.0 & 33.3 & 2.1 & 1.4 & 0.2 & 8.3 & 1.2 & 0.8 & 0.1 \\
\hline Total & 98.9 & 99.9 & 99.9 & 99.5 & 100.4 & 99.8 & 99.5 & 99.4 & 98.7 & 100.3 \\
\hline $\mathrm{Sc}$ & & & & & 2 & 4 & 2 & 3 & 4 & \\
\hline V & & & & 3 & 64 & 32 & 39 & 54 & 27 & 8 \\
\hline $\mathrm{Cu}$ & & & 10 & 2 & 6 & 10 & 13 & 9 & 6 & 7 \\
\hline $\mathrm{Pb}$ & & & & 34 & & 972 & 25 & 20 & 16 & \\
\hline $\mathrm{Zn}$ & 39 & 54 & 151 & 94 & 223 & 3700 & 40 & 161 & 200 & 46 \\
\hline $\mathrm{Rb}$ & & & & 3 & 15 & 27 & 22 & 40 & 34 & 16 \\
\hline $\mathrm{Ba}$ & 14 & 24 & 52 & 18 & 228 & 188 & 568 & 272 & 247 & 110 \\
\hline $\mathrm{Sr}$ & 310 & 180 & 200 & 110 & 660 & 640 & 1700 & 1700 & 1000 & 160 \\
\hline $\mathrm{Li}$ & 3 & 3 & 2 & 5 & 32 & 18 & 19 & 7 & 15 & 8 \\
\hline $\mathrm{Ta}$ & & 0.08 & & & & 0.22 & & & 0.20 & \\
\hline $\mathrm{Zr}$ & 21 & 18 & 20 & 18 & 59 & 64 & 79 & 100 & 80 & 36 \\
\hline $\mathrm{Tb}$ & 0.01 & & & & & 0.24 & 0.17 & 0.11 & 0.47 & \\
\hline Dy & & & & & & & 3.00 & 2.00 & & 5.00 \\
\hline Ho & 0.03 & & 0.78 & & & & 0.09 & 0.08 & 0.35 & \\
\hline $\mathrm{Yb}$ & 0.06 & & 0.54 & & 0.15 & 0.2 & 0.54 & 0.62 & 1.39 & \\
\hline $\mathrm{Lu}$ & 0.01 & & 0.08 & & 0.03 & 0.15 & 0.10 & 0.11 & 0.24 & \\
\hline
\end{tabular}

The marbles have $\delta^{18} \mathrm{O}$ values between +22 and $+28 \%$, which are typical of limestones and marbles elsewhere (Faure 1986). There is no observable geographic control on marble compositions, but few samples have been analyzed. Similarly, there does not appear to be any variation with the type of marble.

The calc-silicate rocks have $\delta^{18} \mathrm{O}$ values ranging from 8 to $23 \%$. The lowest values are similar to the lowest values of the plutons, and the highest are close to those of the marbles. The wollastonite-bearing calc-silicate rocks tend to have somewhat lower $\delta^{18} \mathrm{O}$ values, in the range of $8-13 \%$, than their barren counterparts, except for two outliers, samples abm-101 and abm-111 at 21.4 and $22.9 \%$, respectively. These samples were taken from the northeastern end of the deposit (Fig. 4).

\section{Discussion}

\section{Geology}

Calc-silicates can be produced by isochemical metamorphism of siliceous dolomites and marbles, by metasomatic introduction of silica into pure carbonate rocks, or by a combination of the two processes. None of the outcrops of marble and dolomite in this region have sufficient silica to produce the calc-silicate rocks, although some of the carbonate rocks do have some silica, and there are quartzites (Table 1; Fig. 5).

Most calc-silicate rocks are almost pure diopside or diopside and wollastonite. This is what we would expect if they were produced by metasomatism of almost pure carbonate rocks. Circulating fluids would react with the carbonates and 
Table 2. Whole-rock oxygen isotopic compositions.

\begin{tabular}{llr}
\hline Unit & Sample No. & $\delta^{18} \mathrm{O}(\% o)$ \\
\hline Lac Saint-Jean anorthosite & abm-131 & 8.3 \\
& abm-136 & 9.4 \\
Du Bras pluton & abm-666 & 10.3 \\
Astra pluton & abm-120 & 8.3 \\
& abm-126 & 8.3 \\
Marble & abm-137 & 9.5 \\
& abm-138 & 8.3 \\
& abm-141 & 22.7 \\
& abm-050 & 24.7 \\
& abm-011 & 25.9 \\
Barren calc-silicates & abm-084 & 27.9 \\
& abm-117 & 28.2 \\
& abm-031 & 8.3 \\
& abm-002 & 14.2 \\
Wollastonite-bearing calc-silicates & abm-012 & 15.6 \\
& abm-047b & 16.1 \\
& abm-093 & 18.5 \\
& abm-022 & 8.3 \\
& abm-034 & 8.6 \\
& abm-036 & 10.7 \\
& abm-015 & 12.4 \\
& abm-068 & 12.4 \\
& abm-101 & 21.4 \\
& abm-111 & 22.9 \\
\hline
\end{tabular}

convert them to calc-silicates. When all carbonate was used up there would be no more reactions, and the silica would be transported elsewhere, as it is soluble in hydrothermal fluids. The wollastonite-bearing calc-silicate rocks require either a protolith richer in calcite than the barren calc-silicates or loss of $\mathrm{Mg}$ during metasomatism. If the calc-silicates were produced by metasomatism, then what were the other chemical effects of this process?

\section{Geochemistry}

Open-system geochemical transformations (metasomatism) can involve significant mass loss or gain. This parameter is an important key to the understanding of the geochemistry of the process, but can be difficult to quantify. However, constraints may be established from stoichiometric arguments and various geochemical assumptions.

Wollastonite is commonly produced by the reaction $\mathrm{CaCO}_{3}+\mathrm{SiO}_{2}=\mathrm{CaSiO}_{3}+\mathrm{CO}_{2}$. If all the silica is introduced and all the carbon dioxide is lost, then the stoichiometry of the reaction indicates that there will be a mass gain of $16 \%$. In contrast, if all the silica was originally present in the protolith, then there would be a mass lost of $28 \%$. If the balance of silica and calcite is achieved by removal in solution of excess calcite from a siliceous marble, then much greater mass loss is possible.

The mass change can be calculated from geochemical data if an element can be found that is perfectly conserved during the reaction and whose abundance in the protolith is precisely known (Gresens 1967). All elements can be mobilized under certain conditions, therefore it is not possible to determine, a priori, which elements are conserved in this system.
Nevertheless, we will try to determine which elements appear to have been best conserved. The abundance of the elements most likely to be conserved, such as $\mathrm{TiO}_{2}, \mathrm{Al}_{2} \mathrm{O}_{3}$, $\mathrm{Zr}$, and REE, is very variable in the protolith, as they are not contained in any of the major minerals of the marble. These concentrations are commonly low, and in many samples are below the limit of detection. Hence, it is impossible to ascertain the original concentrations in the protolith.

A commonly applied graphical solution to the equations of Gresens (1967) is the "Isocon" diagram of Grant (1986). In this diagram elemental concentrations of the mean altered rock are plotted against those of the protolith. A best-fit line that passes through the origin describes the mass (or volume) change during metasomatism. However, this diagram has a major weakness, namely that the distance of the points from the origin depends on the scale of the concentration. That is, if the units are changed, for example from parts per million to percent, then the significance of the point to the fitting will change. A simple plot of element ratios avoids this problem. Such a diagram for the mean abundance in the calc-silicates divided by the mean abundance in the protolith marbles is shown in Fig. 6. The largest ratios are shown by the alkali elements $\mathrm{Na}_{2} \mathrm{O}$ and $\mathrm{K}_{2} \mathrm{O}$, but it should be noted that their abundance is very low in the protolith. The "classic" major conserved elements $\mathrm{Al}_{2} \mathrm{O}_{3}$ and $\mathrm{TiO}_{2}$ have ratios of $\sim 4$, whereas the commonly conserved trace elements have lower ratios in the range 1.5-3.

The alkali elements are commonly considered to be among the most mobile elements. Since their abundance increases during the production of calc-silicate rocks, it is unlikely that the calc-silicates were produced by pervasive removal of carbonates from a silica-poor marble. It is much more likely that the alkali elements were precipitated from circulating fluids that also introduced the silica into the protolith. If the production of wollastonite was by introduction of material, rather than removal, then overall changes in the mass of the rock must have been small (+16 to $-28 \%$ ). Therefore, the ratios of the commonly conserved elements indicate that they must also have been introduced. Hence, it is not possible to make a precise calculation of the mass balance. Here, we propose a new type of diagram that better expresses abundance variation in both the protolith and the products.

In this new type of diagram, the abundances of the various components in the wollastonite calc-silicate rocks, barren calc-silicate rocks, and marble are divided by the mean composition of the wollastonite calc-silicate rock abundance. Such a diagram is shown in Fig. 7 for selected elements. The most immediate conclusion from Fig. 7 is that there is no significant chemical difference between the barren calcsilicate rocks and wollastonite-bearing calc-silicate rocks, except for $\mathrm{MgO}$ and $\mathrm{CaO}$. All the elements in this diagram are massively enriched in the calc-silicate rocks, with respect to the protolith, except again for $\mathrm{MgO}$ and $\mathrm{CaO}$. The enrichment is larger than that indicated in Fig. 6, as it is clear that in many samples of the protolith the values are below the detection limit and hence do not contribute to the mean abundance. It is evident that the fluids which brought in most of the silica must have also carried with them many other elements, such as alkalis, alkali earths, $\mathrm{TiO}_{2}, \mathrm{Al}_{2} \mathrm{O}_{3}$, $\mathrm{Zr}$, REE, and Zn. Skarn-forming fluids elsewhere can 
Fig. 5. Chemical variation diagrams for metasedimentary rocks of the Canton Saint-Onge region.

\section{Metasediments}
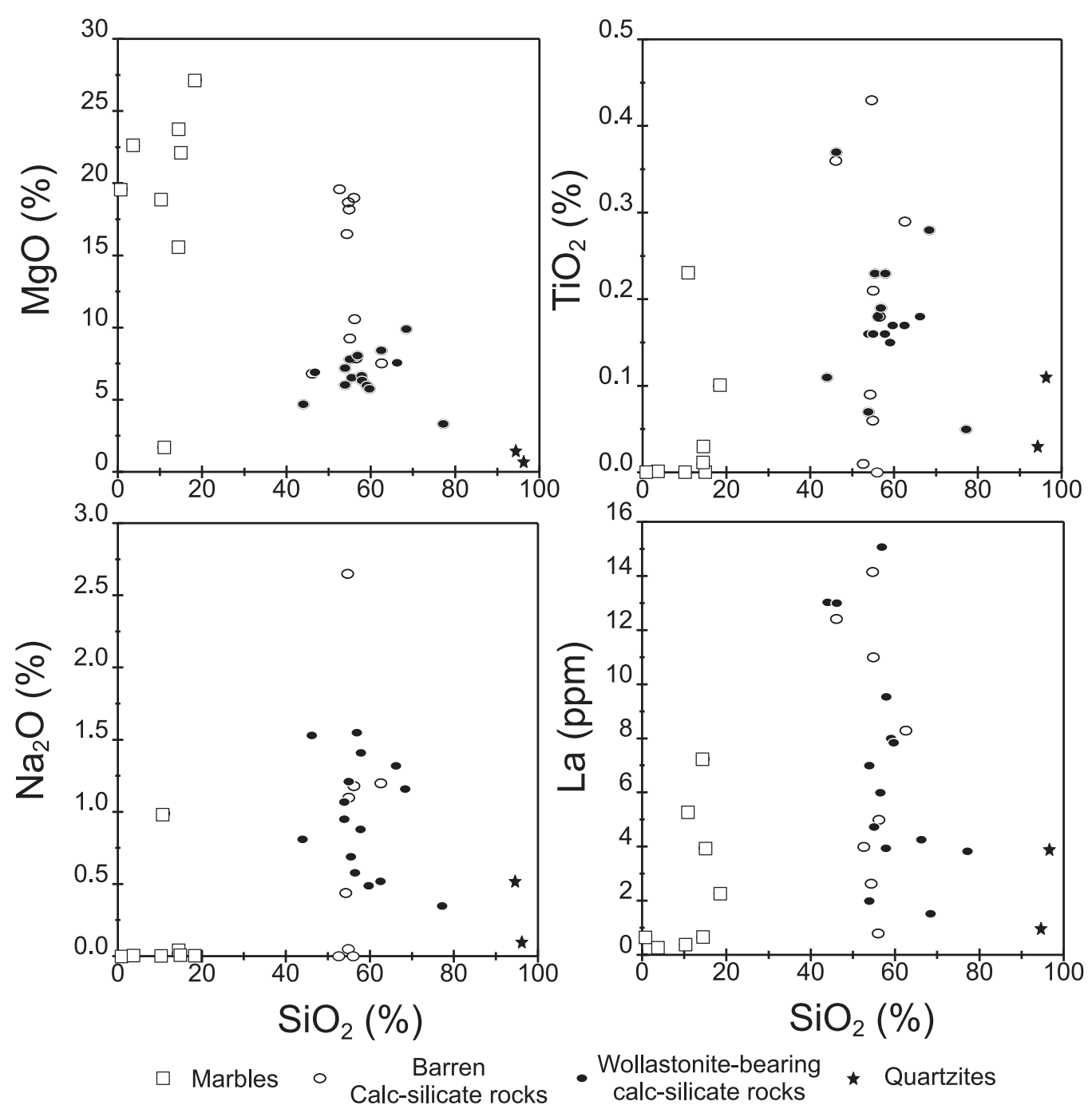

certainly transport these elements (Meinert 1992; Whitney and Olmsted 1998).

\section{Oxygen isotopes}

The whole-rock $\delta^{18} \mathrm{O}$ composition of the calc-silicate rocks depends on the nature of the protolith, the decarbonation process, and the interaction with aqueous fluids. The most reasonable protolith for the calc-silicate rocks is a rock that resembles the marbles of the region with a $\delta^{18} \mathrm{O}$ of +22 to $+28 \%$. Introduction of $\mathrm{SiO}_{2}$ and other elements into this material is certainly capable of producing the calc-silicate rocks.

Transformation of marble or limestone into calc-silicate rocks involves the loss of $\mathrm{CO}_{2}$. The oxygen lost during decarbonation will change the whole-rock $\delta^{18} \mathrm{O}$ value. Two extreme models of decarbonation are possible, batch and Rayleigh distillation, but both are restricted by stoichiometry considerations to maximum $\delta^{18} \mathrm{O}$ fractionations of about $3 \%$ (Valley 1986). This calculation is only strictly true for the

isochemical metamorphism of siliceous dolomites and marbles, where silica is already present in the rock. If silica is introduced by circulating fluids (metasomatism), then larger shifts of $\delta^{18} \mathrm{O}$ are possible. However, such variations are due to the metasomatism and not the decarbonation.

Meteoric fluids can circulate to great depths in the crust and have been implicated in the formation of some wollastonite deposits (Valley 1985; Valley and O'Neil 1982), but the oxygen isotopic compositions of the rocks examined here make this unlikely. Although we do not know the local climate when the deposit was formed, and hence the exact $\delta^{18} \mathrm{O}$ of the precipitation, all meteoric fluids have negative $\delta^{18} \mathrm{O}$. Interaction with such fluids could certainly change $\delta^{18} \mathrm{O}$ values from those of the protolith towards the observed values. However, we would expect to see some $\delta^{18} \mathrm{O}$ values close to zero, or even negative values, for samples that have interacted directly with meteoric fluids. No samples have $\delta^{18} \mathrm{O}$ values below $+8.0 \%$, hence a fluid of this composition is more likely (Fig. 8). Fluids derived from, or equilibrated 
Fig. 6. Ratio of mean compositions of the wollastonite-bearing calc-silicate rocks and barren calc-silicate rocks to the marble. The elements are ordered according to the ratio in the wollastonite-bearing calc-silicate rocks.

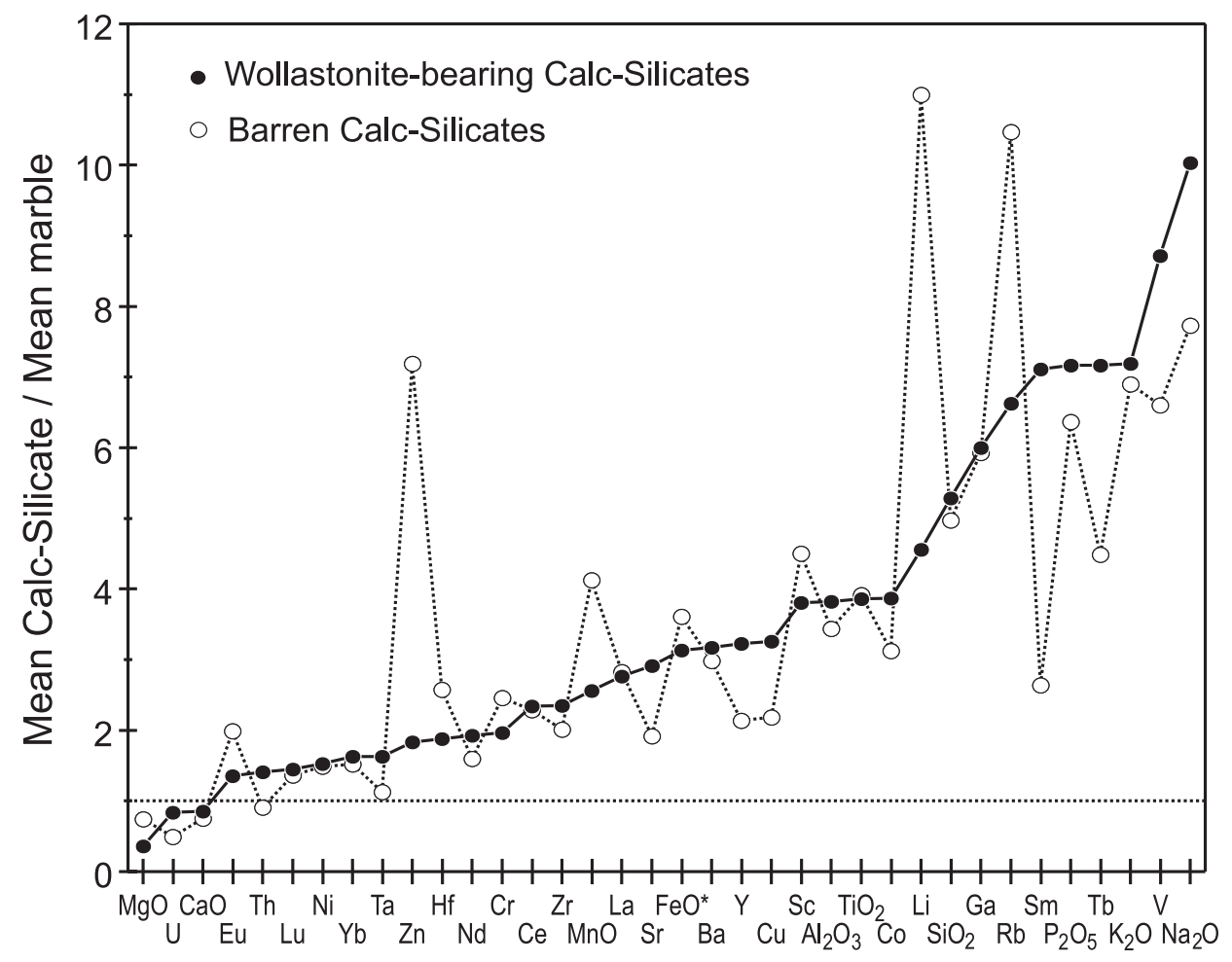

Fig. 7. Comparison of selected elements in the wollastonite-bearing calc-silicates (C-S), barren calc-silicates, and marbles.

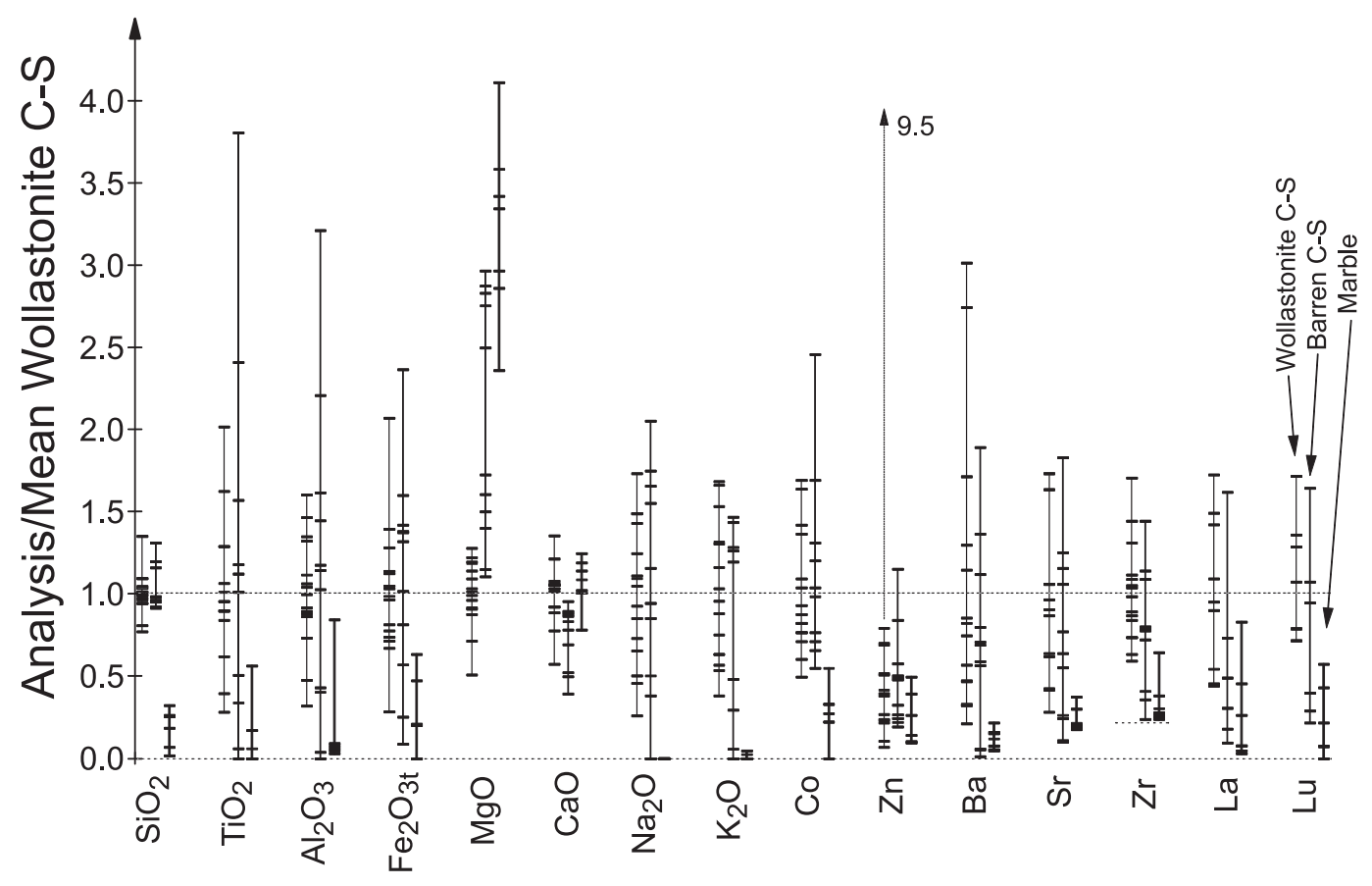

with, the acidic plutons (Du Bras and Astra) could be expected to have $\delta^{18} \mathrm{O}$ values in this range, and hence could have been responsible for the metasomatism.

The generally lower $\delta^{18} \mathrm{O}$ values of the wollastonite-bearing samples suggest that they interacted with more fluids that the barren calc-silicate rocks (Fig. 9). Hence, the difference between the barren and wollastonite-rich calc-silicates may lie in the fluid-to-rock ratio during metasomatism and not in differences in the protolith. Two factors are necessary to produce wollastonite: the mole fraction of $\mathrm{CO}_{2}$ in the fluid must be low (or the temperature very high), and the rock must have a lower $\mathrm{Mg} / \mathrm{Ca}$ ratio than the dolomitic protolith. 
Fig. 8. $\delta^{18} \mathrm{O}($ in $\%$ ) in metasedimentary and plutonic units of the Canton Saint-Onge region.

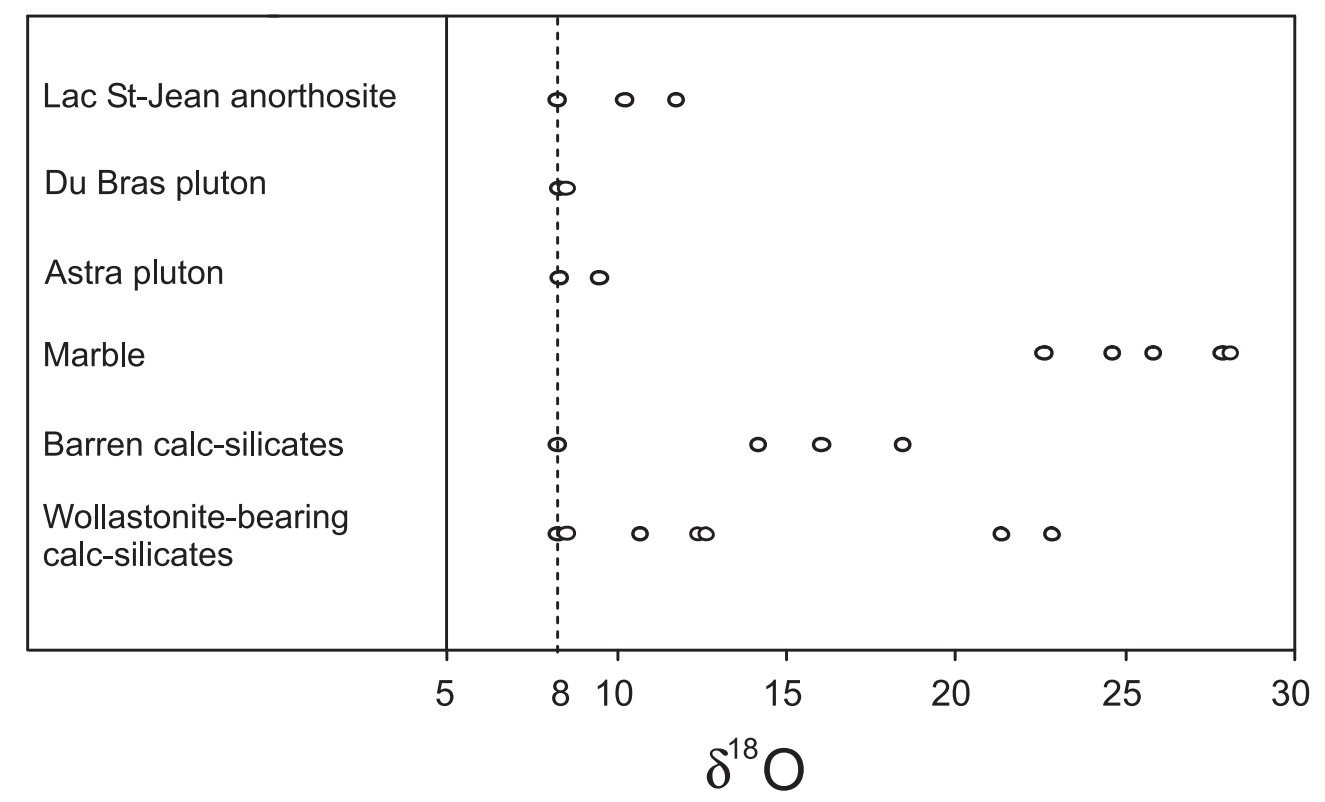

Fig. 9. $\mathrm{Mg} / \mathrm{Ca}$ ratios versus $\delta^{18} \mathrm{O}$ (in $\%$ ) of calc-silicate and carbonate rocks of the Canton Saint-Onge region. Path A is followed by most of the carbonate rocks. It leads from dolomite to diopside-rich rocks. In some areas calcite, produced during the conversion of dolomite to tremolite, is transported in solution and precipitated. This leads to path $\mathrm{B}$ and the production of wollastonite-bearing rocks.

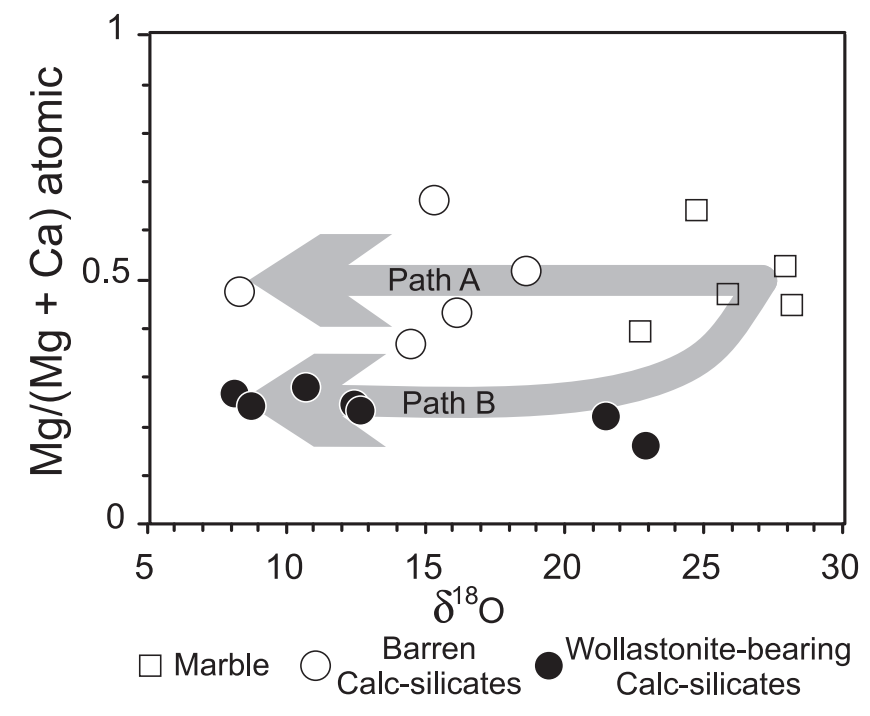

\section{Conclusions}

The calc-silicate rocks of the Canton Saint-Onge region were formed by metasomatism of impure dolomitic marbles similar to the adjacent rocks. Much of the silica necessary for the formation of the calc-silicate minerals was introduced by circulating aqueous fluids. The fluids were mobilized by the nearby Du Bras granitic pluton. However, the fluids must have migrated from greater depths, as there is a screen of unaltered marble between the pluton and the calcsilicate rocks. The fluids appear to have had a magmatic ori- gin. However, meteoric fluids that were completely equilibrated with the Du Bras pluton cannot be excluded.

The fluids that produced the change from carbonatedominated to silicate-dominated mineralogy also introduced significant quantities of other elements (e.g., Al, Ti, Zr, Ba, $\mathrm{Sr}$, and REE), many of which are commonly considered to be conserved during metasomatism. Hence it is not possible to calculate the mass balance of the metasomatic process.

The difference between the wollastonite and barren calcsilicate rocks may reflect differences in the fluid-to-rock ratio during metasomatism. Calcite was dissolved from some areas and reprecipitated in other areas, increasing the $\mathrm{Ca} / \mathrm{Mg}$ ratio. Further fluid fluxing ensured low mole fractions of $\mathrm{CO}_{2}$ and hence the crystallization of wollastonite.

\section{Acknowledgments}

We would like to thank Claude Hébert of the Ministère des Ressources Naturelles du Québec and E.W. Sawyer and other colleagues at Université du Québec à Chicoutimi and Université de Montréal. This paper was completed during a sabbatical at the Department of Geology, Université BlaisePascal, Clermont-Ferrand, France.

\section{References}

Andrews, R.W. 1970. Wollastonite. Institute of Geological Sciences, London.

Ashwal, L.D. 1993. Anorthosites and related rocks. Springer-Verlag, Berlin.

Beisswenger, A. 1997. The origin of the Canton-St-Onge Wollastonite deposit, Lac-St-Jean, Québec. M.Sc., Sciences Appliquées, Université du Québec à Chicoutimi, Chicoutimi, Que.

Christie, B. 1994. Positive feasibility study for wollastonite project. Northern Miner, 80: 1.

Clayton, R.N., and Mayeda, T.K. 1963. The use of bromine pentafluoride in the extraction of oxygen from oxides and silicates for isotopic analysis. Geochimica et Cosmochimica Acta, 27: 43-52. 
Dimroth, E., Woussen, G., and Roy, D.W. 1981. Geologic history of the Saguenay region, Quebec (Central Granulite Terrain of the Grenville Province); a working hypothesis. Canadian Journal of Earth Sciences, 18: 1506-1522.

Faure, G. 1986. Principles of isotope geology. 2nd ed. Wiley, New York.

Fowler, C.M.R., and Nisbet, E.G. 1982. The thermal background to metamorphism; II, simple two-dimensional conductive models. Geoscience Canada, 9: 208-214.

Gervais, R. 1993. Rapport géologique du lac aux Grandes Pointes. Ministère d'énergie et des ressources du Québec, MB 93-14.

Grant, J.A. 1986. The isocon diagram; a simple solution to Gresens' equation for metasomatic alteration. Economic Geology and the Bulletin of the Society of Economic Geologists, 81: 1976-1982.

Greenwood, H.J. 1967. Wollastonite; stability in $\mathrm{H}_{2} \mathrm{O}-\mathrm{CO}_{2}$ mixtures and occurrence in a contact-metamorphic aureole near Salmo, British Columbia, Canada. American Mineralogist, 52: 1669-1680.

Gresens, R.L. 1967. Composition-volume relationships of metasomatism. Chemical Geology, 2: 47-65.

Harker, R.I., and Tuttle, O.F. 1956. Experimental data on the $P$ $\mathrm{CO}_{2}-T$ curve for the reaction; calcite + quartz $\leftrightarrow$ wollastonite + carbon dioxide. American Journal of Science, 4: 239-256.

Hébert, C. 1991. Linéament lacs Saint-Jean - Pipmuacan. In Rapport d'activité. Ministère de l'Énergie et des Ressources, Québec, DV 91-25, p.19.

Higgins, M.D., and van Breemen, O. 1996. Three generations of anorthosite-mangerite-charnockite-granite magmatism, contact metamorphism and tectonism in the Saguenay - Lac-St-Jean region, Grenville Province, Canada. Precambrian Research, 79: 347-362.

Holland, T.J.B., and Powell, R. 1990. An enlarged and updated internally consistent thermodynamic dataset with uncertainties and correlations; the system $\mathrm{K}_{2} \mathrm{O}-\mathrm{Na}_{2} \mathrm{O}-\mathrm{CaO}-\mathrm{MgO}-\mathrm{MnO}-$ $\mathrm{FeO}-\mathrm{Fe}_{2} \mathrm{O}_{3}-\mathrm{Al}_{2} \mathrm{O}_{3}-\mathrm{TiO}_{2}-\mathrm{SiO}_{2}-\mathrm{C}-\mathrm{H}_{2}-\mathrm{O}_{2}$. Journal of Metamorphic Geology, 8: 89-124.

Ider, M., Higgins, M.D., and van Breemen, O. 1997. U-Pb ages of the Canton-St-Onge wollastonite deposit and associated plutons in the central part of the Lac-St-Jean anorthosite complex, Grenville province, Canada. Geological Association of Canada, Program with Abstracts, 22: A72.

MacKinnon, A. 1990. Wollastonite in southern Ontario. Ontario Geological Survey, Open File Report 5715.
Meinert, L.D. 1992. Skarns and skarn deposits. Geoscience Canada, 19: 145-162.

Powell, R., and Holland, T.J.B. 1988. An internally consistent dataset with uncertainties and correlations. 3. Applications to geobarometry, worked examples and a computer program. Journal of Metamorphic Geology, 6: 173-204.

Rivers, T., Martignole, J., Gower, C.F., and Davidson, A. 1989. New tectonic divisions of the Grenville Province, southeastern Canadian Shield. Tectonics, 8: 63-84.

Roy, D.W., Woussen, G., Dimroth, E., and Chown, E.H. 1986. The central Grenville Province; a zone of protracted overlap between crustal and mantle processes. In The Grenville Province. Edited by J.M. Moore, A. Davidson, and A.J. Baer. Geological Association of Canada, Special Paper 31, pp. 51-60.

Taylor, H.P., Jr., and Sheppard, S.M.F. 1986. Igneous rocks. I. Processes of isotopic fractionation and isotope systematics. In Stable isotopes in high temperature geological processes. Edited by J.W. Valley, H.P. Taylor, Jr., and J.R. O'Neil. Mineralogical Society of America, Washington, D.C., pp. 227-271.

Valley, J.W. 1985. Polymetamorphism in the Adirondacks: wollastonite at contacts of shallowly intruded anorthosite. In The deep Proterozoic crust in the North Atlantic provinces. Edited by A.C. Tobi and J.L.R. Touret. D. Reidel Publishing Co., Dordrecht, The Netherlands, pp. 217-236.

Valley, J.W. 1986. Stable isotope geochemistry of metamorphic rocks. In Stable isotopes in high temperature geological processes. Edited by J.W. Valley, H.P. Taylor, Jr., and J.R. O'Neil. Mineralogical Society of America, Washington, D.C., pp. 445-486.

Valley, J.W., and O’Neil, J.R. 1982. Oxygen isotope evidence for shallow emplacement of Adirondack anorthosite. Nature (London), 300: 497-500.

Whitney, P.R., and Olmsted, J.F. 1998. Rare earth element metasomatism in hydrothermal systems: the Willsboro-Lewis wollastonite ores, New York-a differentiated A-type suite. Geochimica et Cosmochimica Acta, 62: 2965-2977.

Winkler, H.G.F. 1974. Petrogenesis of metamorphic rocks. SpringerVerlag, New York.

Woussen, G., Dimroth, E., Corriveau, L., and Archer, P. 1981. Crystallization and emplacement of the Lac-St-Jean anorthosite massif (Québec, Canada). Contributions to Mineralogy and Petrology, 76: 343-350. 